\title{
Thematic Learning in Kindergarten Based on Al-Islam Kemuhammadiyahan and Local Wisdom
}

\author{
Duriani $^{\circledR}{ }^{\bowtie}$, Bahaking Rama ${ }^{2}$, Hadi Pajarianto ${ }^{3}$, Puspa Sari $^{4}$ \\ Pendidikan Guru Pendidikan Anak Usia Dini, Universitas Muhammadiyah Palopo(1,3,4) \\ Pendidikan Agama Islam, Universitas Islam Negeri Alauddin Makassar ${ }^{2}$ \\ DOI: $\underline{10.31004 / o b s e s i . v 5 i 2.1171}$
}

\begin{abstract}
This research is motivated by the preservation and implementation of religious values and local wisdom, it is a case study with a qualitative approach, where the data collected from observation and interviews. The results showed that the Al-Islam kemuhammadiyahan and local wisdom value had been described in the lesson plan and the learning implementation. The value of the Dewata Seuwae is a form of instilling faith in children by introducing Allah creation, the holy book, and the Prophet. The values of alempureng and amaccangang are instilled so that they are always honest. Agettengeng means adherence to principles and responsibility to the ummah, nation, and state. The value of aperrukeng is a child's primary asset for cooperation and a sense of caring for the people around them. This research proves that religion and culture can coexist harmoniously, and their values can be used in thematic Learning in early childhood.
\end{abstract}

Keywords: thematic; al-islam kemuhammadiyahan; local wisdom; kindergarten

\begin{abstract}
Abstrak
Penelitian ini dilatarbelakangi untuk pelestarian dan penerapan nilai-nilai agama dan kearifan lokal, merupakan studi kasus dengan pendekatan kualitatif, dimana data dikumpulkan dari observasi dan wawancara. Hasil penelitian menunjukkan bahwa nilai kemuhammadiyahan dan kearifan lokal Al-Islam telah dijelaskan dalam RPP dan pelaksanaan pembelajaran. Nilai Dewata seuwae merupakan bentuk penanaman keimanan pada anak dengan memperkenalkan ciptaan Allah, kitab suci, dan Nabi. Nilai-nilai alempureng dan amaccangang ditanamkan agar selalu jujur. Agettengeng berarti ketaatan pada prinsip dan tanggung jawab kepada ummah, bangsa, dan negara. Nilai aperrukeng merupakan aset utama anak untuk kerjasama dan rasa kepedulian terhadap orang disekitarnya. Penelitian ini membuktikan bahwa agama dan budaya dapat hidup berdampingan secara harmonis, dan nilai-nilainya dapat digunakan dalam pembelajaran tematik pada anak usia dini.
\end{abstract}

Keywords: tematik; al-islam kemuhammadiyahan; kearifan lokal; taman kanak-kanak

Copyright (c) 2021 Duriani, Bahaking Rama, Hadi Pajarianto, Puspa Sari

$\triangle$ Corresponding author:

Email Address: duriani@umpalopo.ac.id (Kota Palopo, Sulawesi Selatan)

Received 1 March 2021, Accepted 7 March 2021, Published 8 March 2021 


\section{INTRODUCTION}

In essence, education plays a role in the process of improving the quality of human resources. Ki Hajar Dewantara defines education as all efforts from parents to children with the aim of advancing the child's life, improving the growth of all spiritual and physical strength that exists in children because of their iradat nature or their own nature. So a strong national education system is needed to develop students' potential so that they can become human beings who believe in God Almighty, have a noble character, healthy, knowledgeable, capable, creative, independent, and become democratic and responsible citizens. This goal will bring students to become individuals who have an Indonesian identity (Suwardana, 2018).

Early childhood education as a form of education focuses on laying the foundation towards religious and moral growth and development, physical motor skills, cognitive, language and communication, social emotional, in accordance with the uniqueness of the stages of development that early childhood goes through. One of the efforts made to meet children's needs is that services are needed to lead to a process to facilitate growth as laying the right foundation for early childhood growth so that they can develop their potential optimally. This form of service is reflected in law number 20 of 2003 article 1 paragraph 14 which mandates "Early childhood education is an effort of guidance aimed at children from birth to six years of age through educational stimulation to assist physical and spiritual growth and development. children have readiness to enter further education" (Kemdikbud, 2003).

Preparation of children to continue their further education is crucial to the success of children in the future. Because the direction and purpose of early childhood education is none other than to build a foundation in developing the potential of students to become human beings who believe and fear Allah Almighty, have good character, have a noble personality, and become democratic and responsible citizens. Seeing how important the existence of early childhood education is in its implementation, there are many aspects that need to be considered, one of which is educators or teachers. One of the most important views in early childhood education is Pestalozzi's theory, which emphasizes the importance of understanding teachers or parents towards the development of children according to their nature. Child development takes place regularly, progressing step by step so that education must be carried out regularly step by step (Habibi, 2015). In practical terms, the Montessori theory has also been shown to be able to increase children's independence. There is an increase in the average score of the independence scale before and after the Montessori learning method treatment (Damayanti, 2019). About this research, Pestalozzi and Montessori theories can be used as signs in internalizing local wisdom and Al-Islam Kemuhammadiyahan according to children's growth and development.

Aisyiyah as a Muhammadiyah women's movement in 1919 AD, has organized early childhood education named Aisyiyah Bustanul Athfal Kindergarten as a formal educational institution that cannot be separated from the design of learning activities known as curriculum. Aisyiyah has compiled a learning plan in the form of a curriculum and learning model for Aisyiyah Bustanul Athfal Kindergarten as a learning guide or reference for all Aisyiyah Bustanul Athfal Kindergartens throughout Indonesia to be applied in the process of implementing integrated learning with al-Islam Kemuhammadiyahan as Muhammadiyah organization's special characteristics. According to Asmawati, the curriculum is a set of learning plans to achieve learning with the results of certain abilities, skills, attitudes in children that can be observed and measured (Asmawati, 2014).

Learning in early childhood must use the concept of learning while playing, learning by doing, and learning through stimulation. Every child has different abilities and backgrounds so that as much as possible learning can appreciate these differences. The content of the curriculum must be correct and can be accounted for in order to optimize all children's potential and relate to art, beauty, and harmony that leads to happiness in the child's life in accordance with the cultural roots in which he lives and the religious values he adheres to (Aziz, 2017). Kindergarten learning in general is still fixated on the curriculum. The theme and 
activity indicators in the curriculum are the main references in preparing learning activities. In managing education, a teacher is required to have good knowledge of learning. Good knowledge of teachers can also provide good quality to students (Noviana et al., 2019).

Educators should be able to create interesting learning situations for students in the learning process, requiring learning components that influence each other between educators, students and the learning environment. This greatly affects the success of educators in implementing the curriculum. The implementation of the Aisyiyah Bustanul Athfal Kindergarten curriculum which is integrated with Al-Islam Kemuhammadiyahan cannot be separated from the maximum preparation of the teacher to know, understand and be willing to implement this curriculum optimally, although basically not all teachers apply Aisyiyah Bustanul Kindergarten curriculum. Athfal well, teachers still find difficulties so that they are still synergizing with the 2013 curriculum in the implementation process, so one of Aisyiyah's efforts to overcome this is by holding workshops on the implementation of the kindergarten curriculum. Aisyiyah integrates al-Islamic Kemuhammadiyahan in various aspects of child development in achieving Aisyiyah's educational goals, namely infilling the seeds of faith and piety to Allah SWT. as early as possible in the child's personality, educate children with good character and be able to develop all their potential optimally in a conducive environment. Norma Tarazi explained that if children are raised with noble moral guidance from parents and a conducive environment, they will have many figures to emulate and help in the formation of an Islamic personality (Tarazi, 2003).

The implementation of Aisyiyah's early childhood education curriculum includes the basic framework, the structure of the learning program, the standard level of developmental achievement referring to Aisyiyah's 47th convention of 2010, regarding the improvement of the implementation of early childhood education and Government Regulation no. 17 of 2010 describes the management and implementation of education and programs applied to the Aisyiyah Bustanul Athfal kindergarten institution referring to Permendikbud number 137 of 2014 concerning early childhood education standards, Aisyiyah Bustanul Athfal kindergarten curriculum integrating al-Islamic Kemuhammadiyahan and cultural education and national character according to child development (PP 'Aisyiyah, 2012).

Thematic learning terminology utilizes themes associated with several subjects so that it can provide meaningful experiences to students. Meaningful means that in thematic learning students will be able to understand interrelated concepts from several subjects that are by the needs and age development of students (Iskandar et al., 2019). From the research conducted by Nur Asiyah at Raudhatul Athfal Assalam Jati Agung South Lampung, thematic learning is very relevant to moral cultivation. This research proves that the application of thematic learning can develop children's morale more optimally if the learning used supports the teaching materials to be delivered (Asiyah, 2020). Teachers must consider the meaning of themes in building quality and memorable learning experiences for early childhood. Therefore, in determining a theme it is important if it begins with the identification of the theme and at the same time the child's interest in a particular topic (Kartini \& Waridah, 2018).

Kindergarten educator or teacher Aisyiyah Bustanul Athfal in implementing the curriculum acts as a learning agent and as a facilitator by providing learning convenience for students in order to develop their potential optimally. This is in accordance with PP. No.19 of 2005 article 28 paragraph 1, regarding teachers of early childhood education as learning agents must have pedagogical competence, personality competence, professional competence, and social competence. Teachers are required to be active in preparing effective education through an innovative process. Kindergarten curriculum. Aisyiyah Bustanul Athfal integrated with alIslam Kemuhammadiyahan has been implemented by kindergarten teachers. Aisyiyah Bustanul Athfal Palopo, because the main objective of education in al-Islam Kemuhammadiyahan is to form human learners who are devout, have good character, progress and excel in science and technology as the manifestation of tajdid da'wah Islam amar 
ma'ruf nahi munkar. Its mission is to be a solution and a response to the dryness of the religious spirit in Muhammadiyah education.

The implementation of the Aisyiyah Bustanul Athfal Kindergarten curriculum contains learning programs covering the areas of developing behavior formation and developing basic abilities carried out through play activities, gradually, continuously and habitually. The field of behavior formation is an activity that is carried out continuously in the daily life of children, so that it becomes a good habit, covering the scope of the development of al-Islamic values and morals, as well as social, emotional and independent development. Kemuhammadiyahan education is developed in simple language for students.

Implementation of learning carried out by kindergarten teachers. Aisyiyah Bustanul Athfal Palopo City as a form of implementation of the Aisyiyah Bustanul Athfal Kindergarten curriculum integrated with al-Islam Kemuhammadiyahan which is implemented from kindergarten to tertiary institutions in Muhammadiyah-Aisyiyah (Pajarianto \& Muhaemin, 2020). In practice, Al-Islam Kemuhammadiyahan is combined with local wisdom which has become the norm in certain societies. Among the local wisdoms that are widely used contain the values of Dewata SeuwaE, Agettengeng values, Amaccangang values, Alempureng values and Aperrukeng values in instilling the values of faith, worship, morals and muamalah in various aspects of children's development in achieving spiritual attitudes, social attitudes, knowledge and skills.

Basically, the approach is a point of view of the learning process which is the source of the use and learning methods. The learning approach has attracted many people's attention (Sanjaya, 2008). Continued by Haidlor Ali Ahmad, presenting local wisdom as a cultural synthesis created by local actors through an iterative process, internalization and interpretation of religious and cultural teachings which are socialized in the form of norms and used as guidelines in everyday life for the community (Ahmad, 2010). In fact, the development of local values can also be developed to foster a spirit of tolerance (Pajarianto \& Junaidi, 2020)

This research leads to an approach to local wisdom in the form of advice, words of wisdom are reflected in the values that apply to certain groups of people. Nuraeni Asriati said that the form of local wisdom in society is in the form of culture (values, norms, ethics, beliefs, customary law and special rules). Noble values are related to local wisdom such as love for God and its contents, responsibility, discipline, honesty, respect and courtesy, caring, kindness and humility, hard work, creativity and tolerance, love peace and maintain unity (Asriati, 2012). The application of noble values has been internalized through al-Islam Kemuhammadiyahan education in the learning process of TK.ABA City of Palopo, although it is still limited.

Based on description above, the implementation of Aisyiyah Bustanul Athfal kindergarten curriculum which is based on al-Islam Kemuhammadiyahan, with a local wisdom approach, has not been implemented optimally and needs to be improved, with the involvement of teachers, school principals, managers and foundation administrators as education providers to always work. equal in achieving educational goals.

\section{METHODS}

This type of research is a case study with regard to practical reality, application and development of science that occurs in real life. The case study approach is limited as an approach by focusing on a case intensively and in detail (Sukardi, 2009). The form of this research is qualitative research in the form of case studies, the point is to examine the life of an organization or individual who is used as a unit of analysis of ongoing events or symptoms. (Rahardjo, 2012).

This research was conducted at Aisyiyah's charity business location in Palopo City, which is located in Wara, North Wara, Bara and Sendana Districts, Palopo City. These four locations, research is carried out with regard to practical realities, the application and 
development of applied learning so that the problems raised by researchers can be resolved, and at the same time finding solutions to solve existing problems. The presence of researchers is as a planner, implementer of data collection, data analyzer, and also a reporter of the research results. (Figure 1)

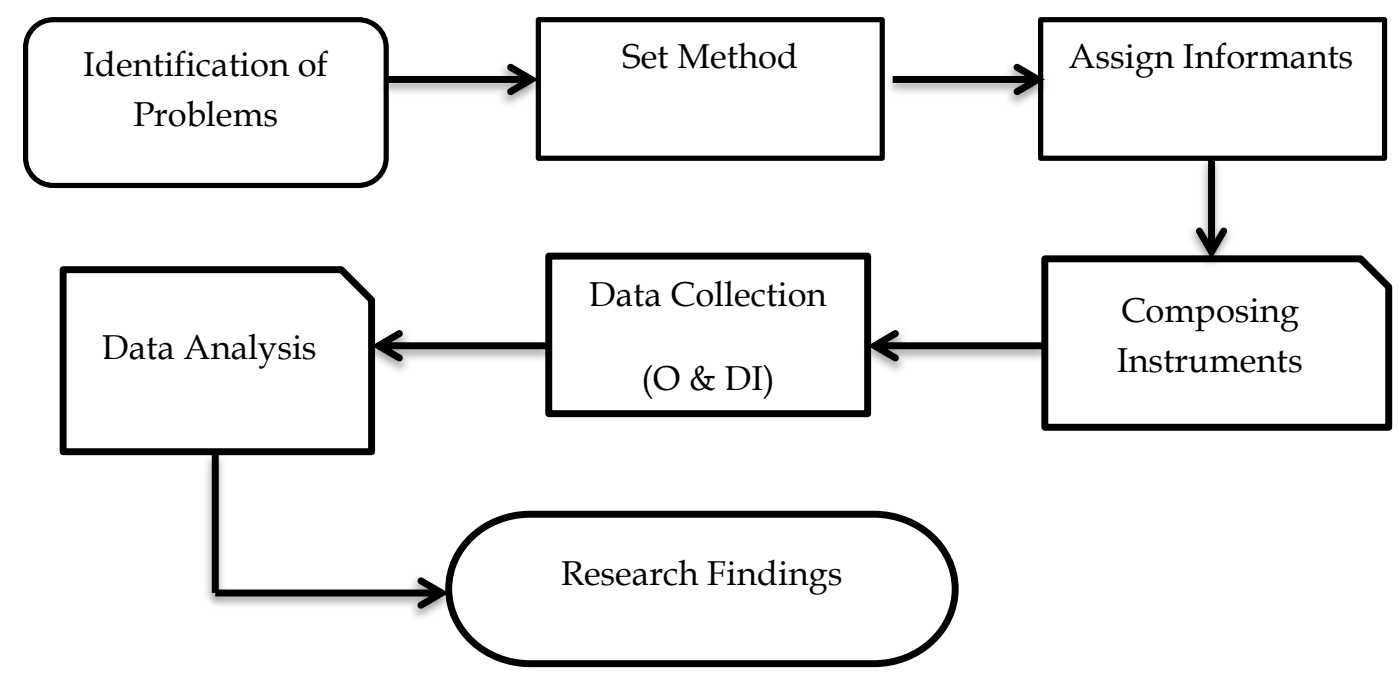

Figure 1. Research Flow

Data collection with; (1) observation as a scientific method is defined as observation which includes focusing attention on an object by using all the senses (Bawani, 2016). The method of observation is done by making direct observations in kindergarten. Aisyiyah Bustanul Athfal by directly observing the teaching and learning process of TK ABA Palopo City teachers, using tools in the form of pictures, recordings and written notes from researchers; and (2) depth interviews. Interviews were conducted by two parties, namely the interviewer with the interviewee by asking measurable questions to explore the information needed by the researcher (Rianto, 1996). Meanwhile, researchers as a key instrument. The informants were 10 teacher representations from 5 Kindergarten, Raudatul Athfal Aisyiyah, Palopo City. They are educators who have more than 5 years of teaching experience.

Data processing and analysis of the main components must be well understood. These components are data reduction, data review and verification or conclusion (Miles \& Huberman, 1992). With this series of processes, it is expected that the data will be truly valid.

\section{RESULT AND DISCUSSION}

Based on the results of interviews and observations, the researcher reduces the data by describing the findings of the data as follows: (1) Aisyiyah Bustanul Palopo Kindergarten has accepted non-Muslim students as a form of Muhammadiyah organization da'wah. (2) The procurement of facilities for the kindergarten building for Aisyiyah Bustanul Athfal I, II, III and IV is the result of donated land from the administrators of Aisyiyah and Muhammadiyah Palopo. (3) Some Kindergarten Teachers. Aisyiyah Bustanul Athfal III is still a high school graduate. (5) Kindergarten curriculum. Aisyiyah Bustanul Athfal is integrated with al-Islam Kemuhammadiyahan with the use of local wisdom that has not been implemented optimally, only limited to reflecting the value of Dewata SeuwaE, Agettengeng value, Alempureng value, Amaccangang value and Aperrukeng value.

Thematic learning designs are carried out by incorporating the values of Al-Islam Kemuhammadiyahan and local wisdom in achieving educational goals. In detail can be seen in the image below. 


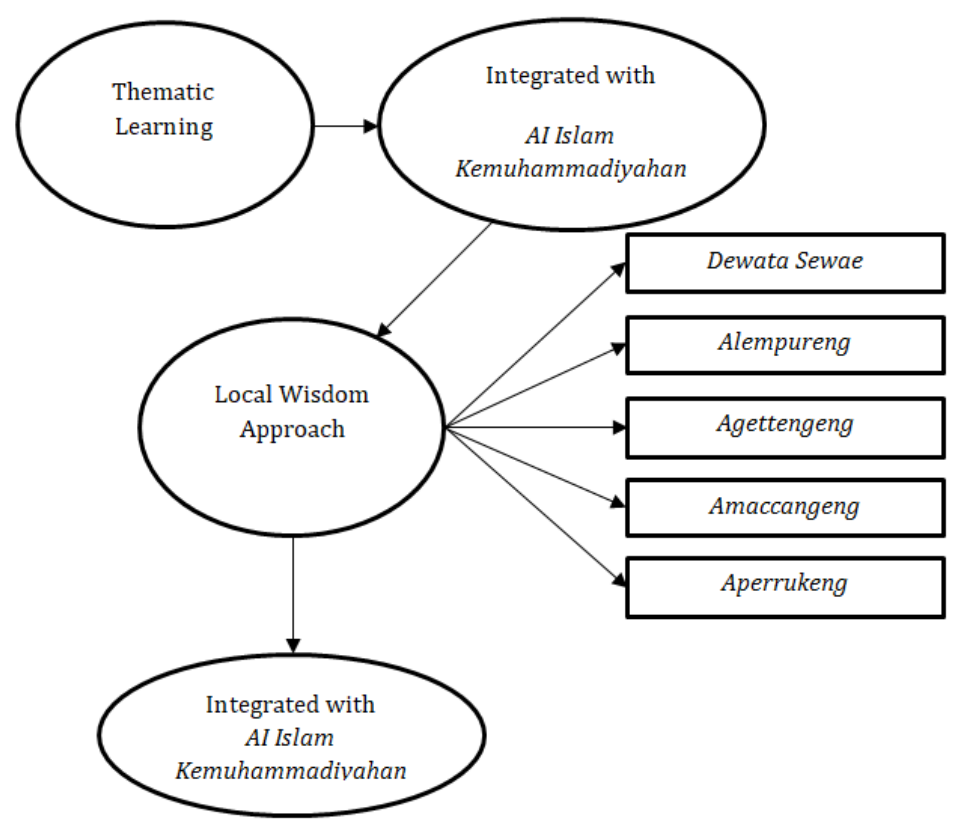

Figure 2. Thematic Learning Design based on Al-Islam kemuhammadiyahan-Local Wisdom

Figure 2 provides an understanding that the thematic learning used is integrated with AIK with the practice of the noble cultural values of Tana Luwu, which must be developed by cultivating the values of the Goddess of Seuwae as a form of cultivation of faith in participants who are free from shirk, bid'ah and khurafat. The value of Alempureng is a form of moral cultivation which is contained in Muhammadiyah's Islamic life guidelines. The value of Agettengeng is a form of children's obedience in carrying out prayers based on practical worship which is decided in the tarjih Muhammadiyah. The value of Amaccangang and Aperrukeng as a form of infilling muamalah for students to always do good by always caring, helping and respecting friends, competent and careful in acting in everyday life. From Mutmainnah's research, this value is a form of Pappaseng (message) which is conveyed orally by wise men in Bugis society against the ruling king or parents which aimed to form good character (Mutmainnah, 2018). The value of local wisdom can be started from the stage of introduction and habituation to children's behavior that they can recognize and feel behind this value (Suwardi \& Rahmawati, 2019). The cultural noble messages of a society can be used as values and norms in society to regulate even as a collective identity that unites it with the community in its environment.

The implementation of the thematic learning design based on Al-Islam kemuhammadiyahan with Local Wisdom at Aisyiyah Bustanul Athfal Kindergarten was carried out by compiling a Learning Implementation Plan, including preliminary activities, core activities and closing activities. In general, the lesson plans made by the informants (Dr, $\mathrm{Bd}, \mathrm{Ft}, \mathrm{Er}, \mathrm{Nr}, \mathrm{Dn}, \mathrm{Hd}$, and $\mathrm{Mn}$ ) are as on table 1.

According to SP, thematic learning integrated with al-Islamic education Kemuhammadiyahan is a hallmark of the kindergarten curriculum. Aisyiyah Bustanul Athfal aims to instill the seeds of faith and devotion to Allah in personality, educate children with noble character and help develop all children's potential optimally, so that it is appropriate to do it in the form of local wisdom containing the values of Dewata Seuwae, Alempureng value, Amaccangang value, value Agettengeng and Aperrukeng values.

This statement was corroborated by $\mathrm{Nr}$ who stated that the learning process was implemented in kindergarten. Aisyiyah Bustanul Athfal II, all aspects of development from religious moral values, social emotional, language, cognitive, motoric, art are integrated with the Islamic values of Kemuhammadiyahan by providing memorization of short surahs and daily prayers. guided directly by the teacher who teaches. Every Saturday there are religious activities such as the practice of ablution, introduction to prayer movements and the reading 
is guided directly by the teacher, as a form of talent development, followed by talent development activities by introducing the art of dance. Implementation of learning with a group learning model with safety activities, RPPH contains preliminary activities, core activities, starting with core activities, rest activities and closing activities.

Table 1. Stages of Learning Activities

\begin{tabular}{|c|c|}
\hline Activities & Activity Details \\
\hline Opening Activities & $\begin{array}{l}\text { The activity begins with praying, singing, discussing the theme, the scope of } \\
\text { the material, and the activities carried out and getting used to starting the } \\
\text { activity by reading books or other reading according to the theme for } \\
\text { developing children's vocabulary and imagination }\end{array}$ \\
\hline Core activities & $\begin{array}{l}\text { provide opportunities for children to have learning experiences through } \\
\text { playing, interacting with other children, exploring, appreciating during } \\
\text { activities so that children's attitudes, knowledge and skills develop, } \\
\text { developing scientific approaches to children through observing, questioning, } \\
\text { gathering information, reasoning, and communicating, clearing play tools } \\
\text { that have been used and establishing effective and positive communication } \\
\text { with students in an effort to shape children's personalities and build } \\
\text { character while providing opportunities for children to recount what they } \\
\text { have done during play activities. }\end{array}$ \\
\hline Activity Break & $\begin{array}{l}\text { and mealtime by inviting children to wash their hands in an orderly manner } \\
\text { and take supplies, eating and drinking utensils, have conversations about } \\
\text { healthy food and drinks that children have, invite children to pray before } \\
\text { eating, invite them to enjoy lunch, invite children to clean up their eating and } \\
\text { drinking utensils, invites children to pray after eating, provides } \\
\text { opportunities for children to play freely inside or outside under supervision } \\
\text { and guidance. }\end{array}$ \\
\hline Closing Activities & $\begin{array}{l}\text { invites children to gather to discuss activities that have been carried out and } \\
\text { convey messages for the next day's activities, confirm the behavior that the } \\
\text { child has raised (thank you for the expected behavior, and discuss } \\
\text { inappropriate behavior) then connect with future activities, carry out } \\
\text { activities calming the singing method, giving examples, telling / telling } \\
\text { stories by inviting children to pray before going home (fun, joyful), allowing } \\
\text { the children to tidy up personal equipment to be brought home in an orderly } \\
\text { manner. }\end{array}$ \\
\hline
\end{tabular}

Source: Teachers' Lesson Plan of Aisyiyah Bustanul Athfal's Kindergarten, Palopo City

Aisyiyah Kindergarten designed the activity plan to be carried out in one day which was taken from the weekly lesson plan. The steps in preparing RPPH are arranged based on weekly activities, daily activities contain the main opening and closing. Kindergarten teachers Aisyiyah, in starting learning activities, before entering class they first arrange daily activities according to the conditions of their respective education units and use a scientific, integrative thematic approach, in developing indicators of learning achievement. Media or learning resources and methods Providing examples, storytelling/stories, methods of advice and prohibitions according to the learning activities to be carried out. Education units can make daily activities in a format according to their individual needs. RPPH contains opening activities, core activities, rest, and closing activities.

The findings above are in line with Kartini's research results, in the Early Childhood Education in Malawi; first, a planning-based theme is carried out by all educators at the beginning of the school year. Second, the thematic learning implementation is based on principles of thematic learning, namely the closeness of the theme to the child's life, attractiveness to children, and incidental themes in learning. Third, thematic learning assessments are used on conversational assessments, observations, project assignments, children's work, and development achievement scales, and also the anecdotal notes are carried 
out regularly so that parents know the child's unusual behavior and not just become a formality (Kartini \& Waridah, 2018).

From the two interviews, the researcher found that there were similarities in the learning process, especially in the stages of opening activities, core activities, rest activities and closing activities. Furthermore Darmatang, in compiling RPPH tries to formulate the items needed in implementing learning in kindergarten of Aisyiyah Bustanul Athfal of Palopo City. It can also be analyzed that the implementation of the learning programmed in kindergarten. Aisyiyah Bustanul Athfal should carry out learning with the aim of being able to directly touch the attitudes, intellectual abilities and psychomotor abilities of students. Using a local wisdom approach that contains the values of Dewata Seuwae, Alempureng, Agettengeng, Amaccangang and Aperrukeng values in achieving the goals of the kindergarten curriculum. Aisyiyah in cultivating faith, worship, morals and muamalah students.

Summary of the implementation of thematic learning based on Al-Islam Kemuhammadiyahan describes as on figure 3.

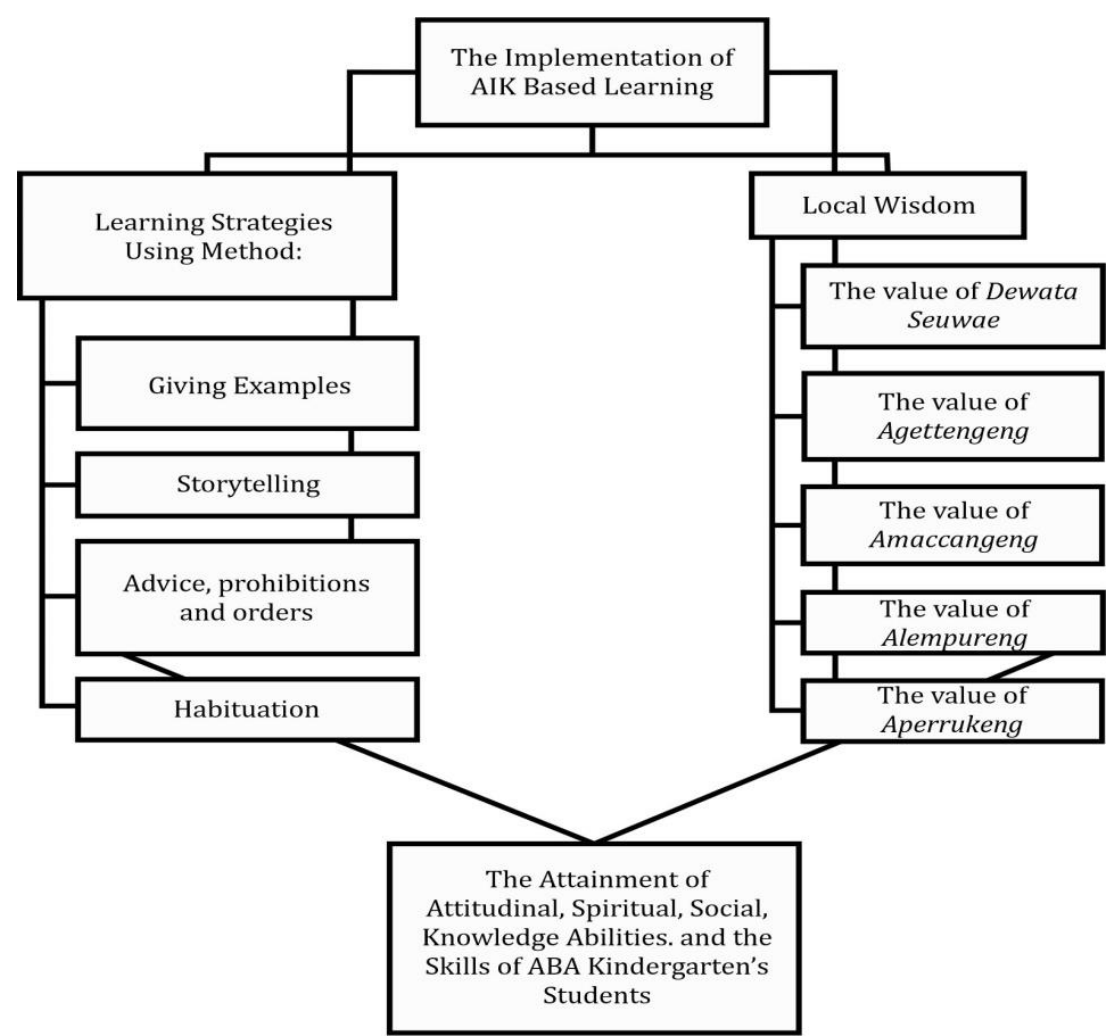

Figure 3. Resume of Thematic Learning Implementation based on Al-Islam kemuhammadiyahanLocal Wisdom

In figure 3, ABA Kindergarten utilizes Al-Islam Kemuhammadiyahan and the five Pangngadereng Luwu values are a component of attitude that must grow in students in achieving the goals of TK education. Aisyiyah has an impact on children's behavior in everyday life. The value of the Gods of Seuwae is a form of instilling faith in children through the introduction of God's creation, the religion he professes, the holy books and the Prophet and Messenger of Allah. The values of alempureng and amaccangang are instilled in the child's personality from an early age so that they are always honest, are the forerunners of children who are intelligent and dexterous in thinking. Agettengeng means obedience / firmness and having strong principles so that children can become trustworthy and responsible leaders to the ummah, nation and state. The value of aperrukeng as the child's main asset to have good cooperation and to have a sense of care for the people around them, so that a high sense of kinship grows in them. 
The learning method used by Kindergarten teacher Aisyiyah Bustanul Athfal, Palopo City, illustrates that the methods used are the method of telling, giving examples, methods of advice, prohibitions and commands, as well as methods of physical and mental experience. according to researchers it must be done repeatedly so that students can easily practice and get used to doing the best things in their daily life.

Furthermore, in the form of worship, it is reflected in the value of Agettengeng as a form of compliance with children in carrying out religious rules, Eppai Gaunna Gettengnge Iyanaritu Tessalai Janci, Tessorosi ulu ada, Telluka Anupura, Teppinra Assituruseng, Mabbicarai Naparapi, Mabbinru'i Teppupi Napaja. This means that there are four forms of obedience, namely not breaking promises, not betraying an agreement, not canceling a decision, if talking and acting do not stop before completion. While the form of moral cultivation is reflected in the values of Alempureng and Amaccangang expressed by pappaseng Aja Nasalaiko Lempu sibawa Acca, Naiya Riaseng Lempu, makessing gau'na, patujui nawanawanna, madeceng ampena, namatau ri dewata (an honest person is always doing good, his heart is calm, good morals and fear of Allah SWT.). Naiya riaseng Acca, de' gaga masussa napegau, de' to have masussa nabali there is madeceng, malemmai, mateppei ripadanna know". (Intelligence is no work that is difficult to do, no questions that are difficult to answer except with tenderness, because he always trusts others).

The instilling of Muamalah is reflected in the value of Aperrukeng as a sense of caring for children to respect, respect and remind each other. Rebba Sipatokkong, Mali Siparape, Siru "i menre tessurui son, malilu sipakainge, maingeppi mupaja. . The learning method used by Kindergarten teacher Aisyiyah Bustanul Athfal, Palopo City, illustrates that the methods used are the method of telling, giving examples, methods of advice, prohibitions and commands, as well as methods of physical and mental experience. according to the researcher, it should be done repeatedly so that students can easily practice and get used to doing the best things in their everyday life.

From the results of research at Kindergarten in Yogyakarta, it was found that a wealth of local wisdom has been used but has not been maximized in the process of stimulating early childhood development. Practicing skills such as carving, playing the gamelan, and tambourines that are practiced by children are almost non-existent in the implementation of early childhood learning. However, painting skills get the best portion in early childhood learning in all districts/cities in DIY. Likewise, the introduction of names for nuclear family members, large families, types of work, traditional games, traditional ceremonies, recognition of names of animals, plants, and time markers have been carried out well in the learning process of early childhood. Learning local wisdom can stimulate children's development as a whole and comprehensively (Pamungkas et al., 2019).

Whereas local wisdom can be an approach to familiarize the character of kindergartenaged children, who are accustomed to reading prayers in playing local wisdom activities and causing joy in playing them. The habit can be done gradually, so that it can be embedded in the child more deeply, so that wherever the child goes, the character of his love for the one and only God who has been attached to him will be lowered. This includes the formation of tolerance in children formed by games of local wisdom that are applied such as tumbutumbu laiya, maggulaceng, mabbelle, mammini, kaje-kaje capeng, maggungrecce, dragon snake (Ashar, 2017).

After the researcher reduces and displays the data obtained from several informants as a whole, the findings of the data obtained will be concluded in the expression that in the implementation of learning in the Kindergarten Curriculum. Aisyiyah Bustanul Athfal found data in: (1) Kindergarten of Aisyiyah Bustanul Athfal Palopo using the curriculum set by Aisyiyah's Central Executive, which synergizes with the 2013 curriculum in making RPPH. Teachers as curriculum implementers are expected to be more focused on achieving Aisyiyah's PAUD curriculum goals by instilling the values of faith, worship, morals and muamalah in students. (2) The use of integrated thematic learning with al-Islam Kemuhammadiyahan with the family group learning model needs to be improved along with the development of human resources. 


\section{CONCLUSION}

Based on the research findings and discussion, it can be concluded that the implementation of thematic learning designs based on Al-Islam Muhammadiyah with Local Wisdom is carried out by compiling a Learning Implementation Plan, which includes preliminary activities, core and closing activities. Learning activities using a local wisdom approach that contains the values of Dewata Seuwae, Alempureng, Agettengeng, Amaccangang and Aperrukeng values in achieving the goals of the curriculum in cultivating faith, worship, morals and muamalah for students. The practice of these five values illustrates that students from all aspects of development.

\section{ACKNOWLEDGMENT}

Researchers would like to thank Muhammadiyah Palopo University for encouraging and facilitating this research to be completed. Thanks are also conveyed to the Regional Leaders of Aisyiyah Palopo City and teachers at Bustanul Athfal Kindergarten who are willing to become informants in this research.

\section{REFERENCES}

Ahmad, H. A. (2010). Kearifan Lokal sebagai landasan pembangunan Bangsa. Harmoni Jurnal Multikultural \& Multireligius, 34, 5-8.

Ashar, E. R. (2017). Pembentukan Karakter Berbasis Kearifan Lokal pada Anak Usia TK. QAWWAM, 11(2), 121-132.

Asiyah, N. (2020). Penerapan Pembelajaran Tematik Dalam Penanaman Moral Anak Usia Dini. Journal of Basic Education Research, 1(2), 45-53. https://doi.org/10.37251/jber.v1i2.82

Asmawati, L. (2014). Perencanaan pembelajaran PAUD. Bandung: Remaja Rosdakarya.

Asriati, N. (2012). Mengembangkan Karakter Peserta Didik Berbasis Kearifan Lokal Melalui Pembelajaran di Sekolah. Jurnal Pedidikan Sosiologi Dan Humaniora, 3(2), 106-119.

Aziz, S. (2017). Strategi Pembelajaran Aktif Anak Usia Dini. Yogyakarta: Kalimedia.

Bawani, I. (2016). Metodologi penelitian pendidikan Islam. Sidoarjo: Khazanah Ilmu Sidoarjo.

Damayanti, E. (2019). Meningkatkan Kemandirian Anak melalui Pembelajaran Metode Montessori. Jurnal Obsesi: Jurnal Pendidikan Anak Usia Dini, 4(1), 463. https://doi.org/10.31004/obsesi.v4i1.333

Habibi, M. (2015). Analisis Kebutuhan Anak Usia Dini. Deepublish.

Iskandar, W., Azkia, N., \& Himmatul Hasanah. (2019). Konsep pembelajaran tematik terpadu (Issue June).

Kartini, K., \& Waridah, W. (2018). Implementasi pembelajaran tematik pada pendidikan anak usia dini. JPPM (Jurnal Pendidikan Dan Pemberdayaan Masyarakat), 5(2), 191-201. https://doi.org/10.21831/jppm.v5i2.23132

Miles, M. B., \& Huberman, A. M. (1992). Qualitatif Data Analysis, terj. Tjejep Rohendi Rohidi, Edisi Indonesia: Analisa Data Kualitatif, Jakarta: UI ....

Mutmainnah, S. A. (2018). Pappaseng To Matoa dalam Masyarakat Bugis: Karakter Pendukung Bagi Manusia. https://doi.org/10.31227/osf.io/cwuxg

Noviana, D., Nisa', T. F., \& Karim, M. B. (2019). Tingkat Pengetahuan Guru PAUD tentang Kurikulum 2013. Jurnal PG-PAUD Trunojoyo: Jurnal Pendidikan Dan Pembelajaran Anak Usia Dini, 6(2), 114-124. https:// doi.org/10.21107/pgpaudtrunojoyo.v6i2.6153

Pajarianto, H., \& Junaidi, J. (2020). The Contribution of Family Edification, Mutualism, and Kinships Against The Tolerance Values in Tana Toraja. KARSA: Journal of Social and Islamic Culture, 28(2), 234-251.

Pajarianto, H., \& Muhaemin, M. (2020). Al-Islam Kemuhammadiyahan Bagi Non-Muslim: Studi Empirik Kebijakan Dan Model Pembelajaran. Al-Qalam, 26(2), 237. https://doi.org/10.31969/alq.v26i2.853 
Pamungkas, J., Syamsudin, A., Harun, H., \& Sudaryanti, S. (2019). Survei Pembelajaran Kearifan Lokal di Taman Kanak-Kanak Se-Provinsi Daerah Istimewa Yogyakarta. $A L$ ATHFAL: JURNAL PENDIDIKAN ANAK, 5(1), 1-20. https://doi.org/10.14421/alathfal.2019.51-01

Sistem pendidikan nasional undang-undang Republik Indonesia nomor 20 tahun 2003 tentang sistem pendidikan nasional, 19 Jakarta Direktorat Pendidik. Menengah Umum (2003).

Pusat'Aisyiyah, P. (2012). Pedoman dan Model Pembelajaran PAUD 'Aisyiyah Bustanul Athfal. Jakarta.

Rahardjo, M. (2012). Mengenal lebih jauh tentang studi kasus. Malang: Materi Kuliah Metodelogi Penelitian PPs UIN Maliki Malang.

Rianto, Y. (1996). Metodologi Penelitian Pendidikan Tinjauan Dasar. In Surabaya: SIC.

Sanjaya, W. (2008). Kurikulum Dan Pembelajaran (Teori E Praktek KTSP). Kencana.

Sukardi. (2009). Metodologi Penelitian, Metodologi Penelitian Pendidikan: Kompetensi dan praktiknya. Edisi ketiga. In Bumi Aksara Jakarta.

Suwardana, H. (2018). Revolusi Industri 4. 0 Berbasis Revolusi Mental. JATI UNIK: Jurnal $\begin{array}{lllll}\text { Ilmiah Teknik Dan Manajemen Industri, } 102 . & \end{array}$ https:/ / doi.org/10.30737/jatiunik.v1i2.117

Suwardi, S., \& Rahmawati, S. (2019). Pengaruh Nilai-Nilai Kearifan Lokal Terhadap Pola Pengasuhan Anak Usia Dini (AUD). JURNAL Al-AZHAR INDONESIA SERI HUMANIORA, 5(2), 87. https://doi.org/10.36722/sh.v5i2.347

Tarazi, N. (2003). The Child In Islam: a Muslim Parent's Handbook, terj. Nawang Sri Wahyuningsih. Wahai Ibu Kenali Anakmu: Pegangan Orang Tua Muslim Mendidik Anak. 